\title{
Effect of prepartal ad libitum feeding of grass silage on transcriptional adaptations of the liver and subcutaneous adipose tissue in dairy cows during the periparturient period
}

\author{
S. Selim, ${ }^{* 1}$ T. Kokkonen, ${ }^{*}$ J. Taponen,† A. Vanhatalo, ${ }^{*}$ and K. Elo* \\ *Department of Agricultural Sciences, PO Box 28, FI-00014 University of Helsinki, Finland \\ †Department of Production Animal Medicine, University of Helsinki, Paroninkuja 20, FI-04920 Saarentaus, Finland
}

\begin{abstract}
Prepartal energy overfeeding may predispose cows to a state of increased insulin resistance with greater lipolysis after parturition. The aim of the study was to evaluate the effects of prepartal overfeeding in terms of abundant grass silage ration on the liver and subcutaneous adipose tissue (SAT) gene expression around parturition. Sixteen multiparous Finnish Ayrshire dairy cows were fed ad libitum either grass silage [high energy, HE; $144 \mathrm{MJ} / \mathrm{d}$ of metabolizable energy (ME) intake, $n=8$ ] or a mixture of grass silage, wheat straw, and rapeseed meal [55:40:5 (CON), $109 \mathrm{MJ} / \mathrm{d}$ of $\mathrm{ME}$, $\mathrm{n}=8]$ during the dry period $(58.2 \pm 4.89 \mathrm{~d}$, mean \pm standard deviation). Tissue biopsies and blood samples were collected at $-14( \pm 4.98), 1$, and $7 \mathrm{~d}$ relative to the actual parturition date. The HE cows had greater total dry matter intake, ME intake, and ME balance during the dry period than the CON cows. Compared with CON, the increases in body weight and body condition score were greater in HE during the dry period. Milk yield during the first $2 \mathrm{wk}$ of lactation was not different between the groups. Plasma glucose, nonesterified fatty acids, insulin, glucagon, and $\beta$-hydroxybutyrate did not differ between the groups during the transition period. Dietary treatment did not affect hepatic triglyceride content; however, a delayed increase in hepatic total lipid content was observed in the HE cows at $d 1$ postpartum. Hepatic cytosolic phosphoenolpyruvate carboxykinase $1 \mathrm{mRNA}$ expression was lower in $\mathrm{HE}$ than in $\mathrm{CON}$ at $\mathrm{d} 1$ and 7 postpartum. Adiponectin receptor 1 and 2 mRNA abundance tended to be lower in SAT of HE than CON. Lower lipoprotein lipase, leptin, and stearoyl-coenzyme A desaturase mRNA abundances were observed at d 7 postpartum in SAT of the HE cows compared with the CON cows. We concluded that prepartal ad libitum feeding of grass silage may decrease insulin sensitivity and lipogenesis in SAT during
\end{abstract}

Received October 17, 2014.

Accepted April 15, 2015.

${ }^{1}$ Corresponding author: shaimaa.selim@helsinki.fi peripartal period and may attenuate the increase of hepatic gluconeogenic capacity from propionate compared with a controlled-energy diet.

Key words: prepartal energy, gluconeogenesis, insulin resistance, lipogenesis, dairy cow

\section{INTRODUCTION}

Transition period requires a complex coordination of metabolism in multiple tissues to support the onset of milk synthesis (Block et al., 2001; Grummer et al., 2004). A physiological state of peripheral insulin resistance develops during late pregnancy and plays a key role in the exacerbation of adipose tissue (AT) mobilization near calving (Bell, 1995). Changes in AT secretion of adipokines adiponectin (ADIPOQ) and leptin (LEP), which in the context of obesity play an important role in insulin resistance in humans and rodents (Antuna-Puente et al., 2008), may affect insulin sensitivity also in dairy cows. Ji et al. (2012) reported that excess energy intake prepartum resulted in greater expression of $A D I P O Q$ and led to an enhanced rather than compromised insulin signaling pathway. Selim et al. (2014) observed that overfeeding energy during the first 3 wk of the dry period combined with decreasing energy allowance during the last 3 wk before parturition did not affect the expression of $A D I P O Q, A D I$ $P O Q$ receptors, or $L E P$ in subcutaneous adipose tissue (SAT) of transition dairy cows. The conflicting results suggest that the role of adipokines in dairy cows during the transition period is not fully elucidated.

One of the key consequences of excessive FA mobilization after calving is lipid accumulation in the liver. Murondoti et al. (2004) observed that overfeeding energy during late pregnancy caused a diminished activity of hepatic gluconeogenic enzymes during early lactation, and they attributed this to fatty infiltration of the liver. However, Hammon et al. (2009) reported that increased liver lipid content did not impair the expression of hepatic gluconeogenic genes and Selim et al. (2014) concluded that excess dietary energy intake prepartum resulted in lower expression of hepatic 
gluconeogenesis, whereas no differences in liver lipid content was observed. Nevertheless, based on enzyme activity and gene expression studies, overfeeding energy prepartum may negatively affect hepatic gluconeogenesis, as well as FA $\beta$-oxidation (Murondoti et al., 2004; Loor et al., 2006; Selim et al., 2014).

Peroxisome proliferator-activated receptor $\gamma$ and $\alpha$ (PPARG and PPARA) are key transcriptional factors controlling lipid metabolism via their target genes in the liver and AT (Bionaz et al., 2013). The greater abundance or activation of $P P A R G$ may increase insulin sensitivity in AT and decrease FA mobilization, whereas PPARA may alleviate liver lipid accumulation by increasing oxidation of NEFA and enhancing very low-density lipoprotein synthesis (Bionaz et al., 2013). In addition, PPARA may have a role to control the increase of gluconeogenesis early postpartum (Bionaz et al., 2013).

A better understanding of coordinated changes in transition cow metabolism at the molecular level in responding to prepartal overfeeding may help to develop strategies to decrease the incidence for metabolic diseases. Recent studies have evaluated the effect of prepartal overfeeding of energy in corn-based diets on the liver or SAT gene expression (Ji et al., 2012; Graugnard et al., 2013; Khan et al., 2014). In these studies energy overfeeding is accompanied by increased intake of corn starch, which may modulate glucose absorption from small intestine. Our objective was to assess the effects of ad libitum feeding of grass silage (low starch) throughout the dry period on the liver and SAT gene expressions of transition dairy cows. The hypothesis was that overfeeding of grass silage during the dry period would enhance lipogenesis prepartum and induce a more pronounced SAT mobilization postpartum characterized by changes in SAT gene expression. Additionally, we hypothesized that overfeeding energy would modify the transcriptional activity of the expression of hepatic genes related to glucose metabolism and FA $\beta$-oxidation during the transition period.

\section{MATERIALS AND METHODS}

\section{Animals, Diets, and Experimental Design}

The experimental procedures were approved by the National Animal Ethics Committee in Finland (Hämeenlinna). At the beginning, 16 nonlactating Finnish Ayrshire dairy cows were selected to participate in the study based on parity $(4.0 \pm 1.26$; mean $\pm \mathrm{SD})$, BW $(733 \pm 103.8 \mathrm{~kg})$, and BCS using a 5-point scaling system (3.48 \pm 0.539; Edmonson et al., 1989) in a randomized complete block design. An average 305-d milk yield from the previous lactation of the experimental cows was $10,503 \mathrm{~kg}$. Cows were paired based on the previously mentioned criteria and the expected calving date, and cows within pairs were randomly assigned to dietary treatment groups. The experimental feeding started $58.2 \pm 4.89 \mathrm{~d}$ before the actual parturition date and continued until calving. The dietary treatments were either ad libitum feeding of a high-energy diet $(\mathbf{H E})$ or a controlled-energy $\operatorname{diet}(\mathbf{C O N})$. Chemical composition of diets is presented in Table 1. The HE diet contained grass silage (digestible $\mathrm{OM}=634 \mathrm{~g} / \mathrm{kg}$ of $\mathrm{DM}$ ), whereas the CON diet contained a mixture of grass silage $(55 \%$, digestible $\mathrm{OM}=667 \mathrm{~g} / \mathrm{kg}$ of $\mathrm{DM})$, wheat straw $(40 \%$, digestible $\mathrm{OM}=457 \mathrm{~g} / \mathrm{kg}$ of DM), and rapeseed meal $(5 \%$, digestible $\mathrm{OM}=700 \mathrm{~g} / \mathrm{kg}$ of $\mathrm{DM})$. The diets were formulated to maintain a $100 \mathrm{~g} /$ $\mathrm{kg}$ of DM difference in NDF concentration. Targeted ME intakes during the dry period were $140(\sim 140 \%$ of energy requirement of pregnant dairy cows; LUKE, $2015)$ and $105 \mathrm{MJ} / \mathrm{d}(\sim 100 \%$ of energy requirement of pregnant dairy cows) for $\mathrm{HE}$ and $\mathrm{CON}$, respectively. For the TMR of CON diet, round bales of straw were preprocessed in a mixer wagon for 40 min before grass silage was added to the mixer. After the addition of grass silage, TMR was mixed for $30 \mathrm{~min}$ and, finally, after the addition of rapeseed meal for $10 \mathrm{~min}$. Grass silage or TMR was offered to cows 3 times daily at 0700 , 1300, and 2000 h. During the close-up period, commercial concentrate mixture (Raisioagro Ltd., Raisio, Finland) was added to both groups starting from 1 $\mathrm{kg} / \mathrm{d}$ at d 10 to 6 before the expected calving date and $2 \mathrm{~kg} / \mathrm{d}$ until parturition. Cows had free access to water.

After parturition, all cows were offered wilted grass silage ad libitum and an increasing amount of commercial concentrate. The concentrate ration comprised the same concentrate as before calving and a protein supplement (Raisioagro Ltd.). The proportions of cereal concentrate and protein supplement were 91 and $9 \%$ during the first week of lactation and 87 and $13 \%$ during the second week of lactation, respectively. The total amount of concentrate after calving was $5 \mathrm{~kg} / \mathrm{d}$ at the day of parturition, $7 \mathrm{~kg} / \mathrm{d}$ at $\mathrm{d} 7$ postpartum $(6$ $\mathrm{kg} / \mathrm{d}$ of cereal concentrate $+1 \mathrm{~kg} / \mathrm{d}$ of protein supplement), and $11 \mathrm{~kg} / \mathrm{d}$ at d 14 postpartum $(9 \mathrm{~kg} / \mathrm{d}$ of cereal concentrate $+2 \mathrm{~kg} / \mathrm{d}$ of protein supplement). Individual feed ingredients were sampled weekly, and the forage samples were composited before analysis to form a monthly sample. Samples of each concentrate (cereal concentrate, rapeseed meal, and protein supplement) were pooled to form a 2-mo sample for chemical analyses. Contents of DM, OM, CP, and NDF in the feeds and in vitro OM digestibility of forages were determined using methods described by Salin et al. (2012). The ME contents of forages were calculated based on the concentration of digestible OM in feed DM (D- 
Table 1. Chemical composition of experimental feeds

\begin{tabular}{|c|c|c|c|c|c|c|}
\hline Item $^{1}$ & \multicolumn{3}{|c|}{ Prepartum $^{2}$} & \multicolumn{3}{|c|}{ Postpartum $^{3}$} \\
\hline D-value, $\mathrm{g} / \mathrm{kg}$ of $\mathrm{DM}$ & 587 & 634 & & 687 & & \\
\hline $\mathrm{NDF}, \mathrm{g} / \mathrm{kg}$ of DM & 651 & 528 & 204 & 527 & 204 & 224 \\
\hline $\mathrm{DM}, \mathrm{g} / \mathrm{kg}$ & 289 & 270 & 877 & 288 & 877 & 879 \\
\hline
\end{tabular}

${ }^{1} \mathrm{D}$-value $=$ digestible OM concentration in feed DM.

${ }^{2}$ Sixteen multiparous dairy cows were fed ad libitum either grass silage (HE; $144 \mathrm{MJ} / \mathrm{d}$ of ME intake, $\left.\mathrm{n}=8\right)$ or a mixture of grass silage, wheat straw, and rapeseed meal [55\%: 40\%: 5\% (CON), $109 \mathrm{MJ} / \mathrm{d}$ of ME, $\mathrm{n}=8$ ] during the dry period (58.2 $\pm 4.89 \mathrm{~d}$, mean $\pm \mathrm{SD})$. During the closeup period, commercial concentrate mixture was added to both groups starting from $1 \mathrm{~kg} / \mathrm{d}$ at $\mathrm{d}-10$ to $\mathrm{d}-6$ before the expected calving date and $2 \mathrm{~kg} / \mathrm{d}$ until parturition.

${ }^{3}$ After parturition, all cows were offered wilted grass silage ad libitum and an increasing amount of commercial concentrate starting from 5 $\mathrm{kg} / \mathrm{d}$ at the day of parturition, $7 \mathrm{~kg} / \mathrm{d}$ at $7 \mathrm{~d}$ postpartum $(6 \mathrm{~kg} / \mathrm{d}$ of cereal concentrate $+1 \mathrm{~kg} / \mathrm{d}$ of protein supplement), and $11 \mathrm{~kg} / \mathrm{d}$ at $14 \mathrm{~d}$ postpartum $(9 \mathrm{~kg} / \mathrm{d}$ of cereal concentrate $+2 \mathrm{~kg} / \mathrm{d}$ of protein supplement).

value; LUKE, 2015). The ME contents of concentrates were calculated using feed table values (LUKE, 2015). The cows were kept in tiestalls. Prior to expected calving, cows were moved to individual calving pens and returned to tiestalls after parturition. Daily feed intake was measured using a roughage intake control system (Insentec BV, Marknesse, the Netherlands), fitted with separate concentrate troughs. Cows were milked twice daily at 0600 and $1430 \mathrm{~h}$.

\section{Body and Blood Measurements}

Body weight and BCS were determined at d 56, 42, 28, 14, and 5 before the expected calving and at d 1, 7, and 14 after calving. Blood samples were collected at d $14.3 \pm 4.98$ before the actual parturition date, from the milk vein, and $d 1$ and $7( \pm 1)$ after parturition from the coccygeal blood vessels. The protocol of blood sampling and methods of analyzing blood BHBA and glucagon has been described in Selim et al. (2014). Plasma insulin, NEFA, and glucose were measured using the methods described by Salin et al. (2012). Intra- and interassay coefficients of variation (CV) for glucose measurement were 1.93 and $1.93 \%$, respectively. Intra-assay CV for NEFA and BHBA were 1.81 and $2.20 \%$, respectively. Interassay CV were 2.08 and 1.97 for NEFA and BHBA, respectively. Intra-assay $\mathrm{CV}$ for insulin determination was $7.16 \%$ and interassay CV were 9.95 and $11.56 \%$ for low and medium concentrations, respectively. Intra- and interassay CV for glucagon determination were 4.60 and $9.60 \%$, respectively. The detection limits for insulin and glucagon assays were 1.8 and $19.6 \mathrm{pg} / \mathrm{mL}$, respectively.

\section{Adipose and Liver Biopsies, RNA Extraction, and cDNA Synthesis}

Adipose and liver tissues were collected by biopsy at d $14.3 \pm 4.98$ before the actual parturition date and d 1 and $7( \pm 1)$ after parturition, as described previously by Selim et al. (2014). Adipose tissue samples were snap-frozen immediately after the sampling in liquid nitrogen and stored thereafter at $-80^{\circ} \mathrm{C}$. The liver biopsy was performed immediately after SAT collection, and the samples were preserved in 1.8 $\mathrm{mL}$ Nunc CryoTubes (Fisher Scientific Oy, Vantaa, Finland) containing protective solution (Allprotect solution, Qiagen, Hilden, Germany), incubated at $4^{\circ} \mathrm{C}$ overnight, and stored at $-20^{\circ} \mathrm{C}$ for subsequent use in RNA analyses. Liver samples for triglyceride (TAG) and total lipid analyses were snap-frozen in liquid nitrogen and stored at $-80^{\circ} \mathrm{C}$. Hepatic TAG and total lipid contents were measured as described previously (Starke et al., 2010). Total RNA was extracted from the liver tissue samples using RNeasy Mini Kit and from SAT samples using RNeasy Lipid Tissue Kit (Qiagen) according to the manufacturer's instructions. The RNA quantity and quality were determined following protocols described before (Selim et al., 2014). Total RNA samples from adipose and liver tissues had $260 / 280$ average absorbance ratios of $1.9 \pm 0.41$ and $2.0 \pm 0.03$ and average RNA integrity number values of $6.0 \pm 2.61$ and $8.0 \pm 1.94$, respectively. After quality control, the final number of SAT RNA samples was 41 $(14,13$, and 14 samples at $\mathrm{d}-14,1$, and 7 relative to parturition, respectively). No RNA samples were excluded for the liver. First-strand cDNA was synthesized with Anchored-Oligo (dT) 18 primer using Transcriptor 
First Strand cDNA Synthesis Kit (Roche Diagnostic, Mannheim, Germany) in a $20-\mu \mathrm{L}$ reaction according to the manufacturer's instructions. The cDNA was diluted (1:8) with DNase/RNase-free water.

\section{Primer Design and Quantitative Real-Time PCR}

Primers for evaluated genes were designed using the online Primer3 software program (Rozen and Skaletzky, 2000). The uniqueness of primer sequences was established using BLAST search tool and NCBI GenBank sequence database (http://www.ncbi.nlm. nih.gov/genbank/). The DNA sequences for primers, GenBank accession numbers, PCR product lengths, analyzed tissue(s), and references for published primers are presented in Table 2. The internal control gene used in the current study was eukaryotic translation initiation factor 3 subunit K (EIF3K; Kadegowda et al., 2009; Bonnet et al., 2013). Eukaryotic translation initiation factor 3 subunit $\mathrm{K}$ has been found to be one of the most stable internal control genes in bovine liver and AT (Bonnet et al., 2013). The expression stability of EIF3K was tested using NormFinder software (Andersen et al., 2004), and EIF3K was found to be stable across the groups and time points in the liver and SAT (stability values from 0.19 to 0.24 ). However, the geometric average of more than 1 internal control gene has been suggested to be ideal for normalization of quantitative real-time PCR data (Kadegowda et al., 2009; Bonnet et al., 2013). The quantitative real-time PCR reactions were performed in a LightCycler 480 optical 384-wellplate (Roche Diagnostics) with total volume $10 \mu \mathrm{L}$, as described by Selim et al. (2014). The mRNA abundance was calculated relative to the expression of EIF3K as a reference gene (i.e., the calculation of the expression was based on the difference between the cycle threshold $(\mathrm{Ct})$ values of the target genes and the internal control gene (18- $\Delta \mathrm{Ct})$. Amplification efficiencies were varied from 1.86 to 1.91 and they were calculated using LinRegPCR program version 2014.5, as described by Ruijter et al. (2009).

\section{Calculations and Statistical Analysis}

Statistical computations were performed using SAS (SAS Institute Inc., Cary, NC; release 9.3). Residuals for the entire data set were checked for normality and outliers using the MIXED and UNIVARIATE procedures of SAS. Metabolic measurements that were not normally distributed were $\log _{2}$-transformed to achieve normal residual distribution and are presented as $\log _{2}$-transformed (plasma BHBA, NEFA, glucagon, glucagon-to-insulin ratio, and hepatic TAG and total lipids). A constant (1) was added to BHBA and glu- cagon-to-insulin ratio values before transformation to avoid negative digits. Gene expression data were $\log _{2-}$ transformed $\left[\log _{2}(18-\Delta \mathrm{Ct})\right]$ to normalize the data, and data points with highest studentized residuals $(>2.5)$ were considered outliers and excluded from analysis. In the liver gene expression data, 2 observations were excluded from the analysis [ 1 from cytosolic phosphoenolpyruvate carboxykinase $1(P C K 1 ; \mathrm{n}=47)$ and 1 from DGAT1 $(\mathrm{n}=47)]$. In SAT gene expression data, 1 observation was excluded from the analysis of $A D I P O Q$ $(\mathrm{n}=40)$ and adiponectin receptor 1 (ADIPOR $1 ; \mathrm{n}=$ $40)$ and 2 observations were excluded from the analysis of PPARG $(\mathrm{n}=39)$.

In the final statistical analysis, repeated measures ANOVA were conducted using the MIXED procedure of SAS (release 9.3). The statistical model included fixed effects of treatment, time, the interaction between treatment and time, and random effects of block and the interaction between block and time. When the interaction of treatment and time was significant, differences between treatments at each time point were tested for significance using the slice option of the SAS MIXED procedure. For each variable analyzed, cows nested within the treatment were subjected to 3 covariance structures: compound symmetry, unstructured, and spatial power law. The covariance structure that resulted in the smallest Bayesian information criterion was used. Significance was declared as $P<0.05$ and trends as $0.05 \leq P \leq 0.15$. Spearman rank correlation coefficients were calculated between genes, blood parameters, and hepatic TAG using SPSS software (SPSS Inc., Chicago, IL, version 22) to identify significant $(P$ $<0.05)$ correlations.

\section{RESULTS}

\section{Feed Intake, Live Weight, and Body Condition}

Feed intake during the dry period is presented in Table 3. The HE group had greater total DMI $(P=$ $0.002)$, ME intake $(P<0.001)$, and ME balance $(P$ $=0.001)$ during the dry period than the CON group. The HE cows had a greater forage intake (treatment $x$ week, $P=0.05)$ during the last 2 wk of pregnancy ( $P$ $=0.04$ and $P=0.03$ at wk -2 and -1 before expected calving, respectively) compared with the CON cows, but no differences were noted between the groups at wk 1 and 2 postpartum (Table 4). Total DMI during the transition period (between wk -2 to 2 relative to parturition) did not differ between the groups and increased after parturition when compared with before parturition. Metabolizable energy intake (treatment $x$ week, $P=0.11$ ) was greater in the HE group than in the CON group before parturition $(P=0.02$ and $P$ 


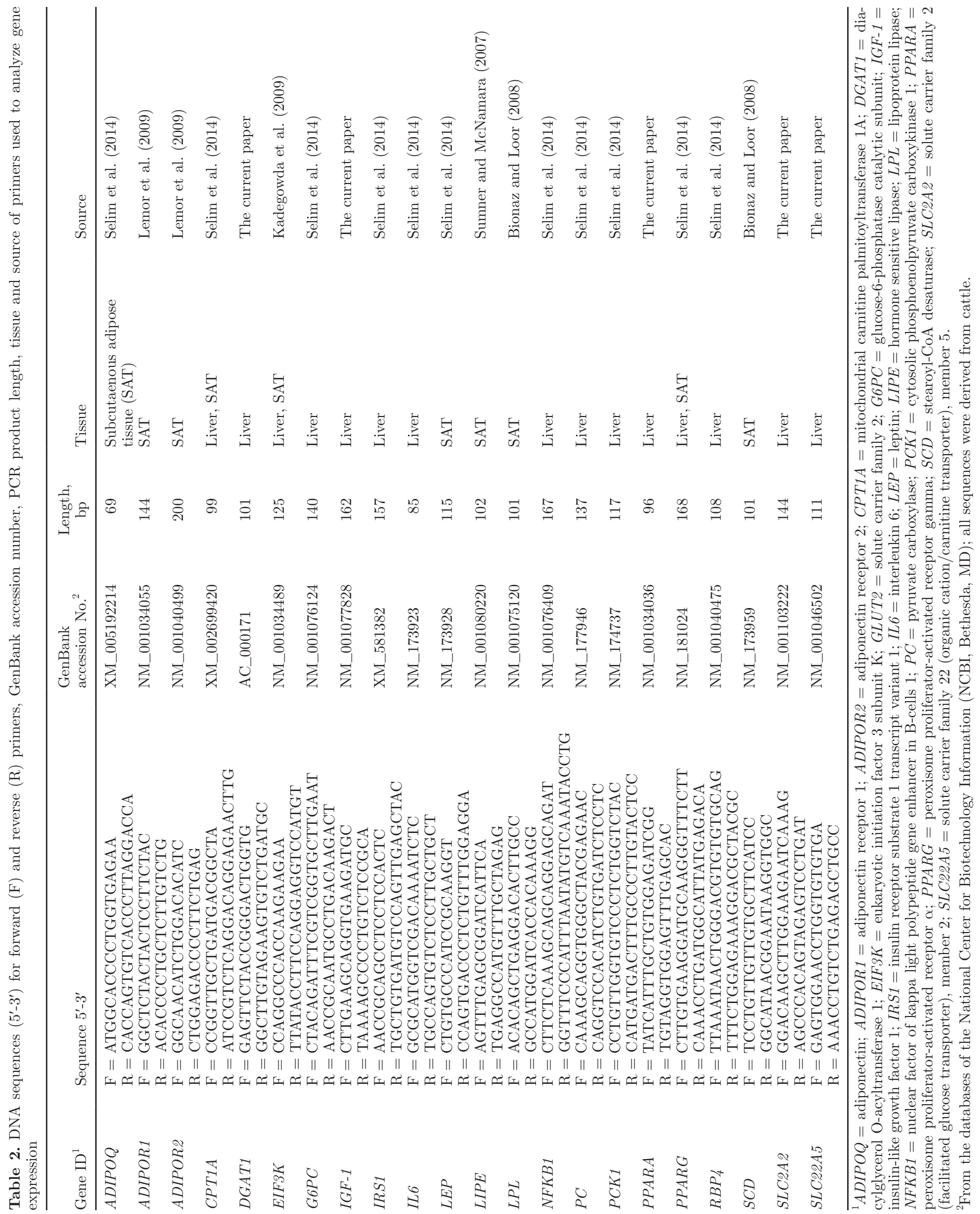


Table 3. Feed intake during the dry period from wk -8 to -1 relative to expected parturition

\begin{tabular}{|c|c|c|c|c|c|c|}
\hline \multirow[b]{2}{*}{ Item $^{1}$} & \multicolumn{3}{|c|}{ Treatment $^{2}$} & \multicolumn{3}{|c|}{$P$-value ${ }^{4}$} \\
\hline & $\mathrm{CON}$ & $\mathrm{HE}$ & $\mathrm{SEM}^{3}$ & Trt & Wk & Trt $\times W k$ \\
\hline Total DMI, kg/d & 12.0 & 14.2 & 0.50 & 0.002 & 0.55 & 0.64 \\
\hline $\mathrm{ME}, \mathrm{MJ} / \mathrm{d}$ & 109.0 & 144.2 & 4.85 & $<0.001$ & 0.79 & 0.52 \\
\hline ME balance, $\mathrm{MJ} / \mathrm{d}$ & 8.5 & 39.4 & 5.11 & 0.001 & 0.02 & 0.46 \\
\hline
\end{tabular}

$=0.03$ at $\mathrm{wk}-2$ and -1 before expected parturition, respectively), but after parturition there was no difference. The ME balance was greater (treatment $\times$ week, $P=0.02)$ in HE than in CON prepartum $(P=0.03$ and $P=0.01$ at wk -2 and -1 before expected parturition, respectively), but no difference was observed between the groups at wk 1 and 2 postpartum. Milk yield during the first 2 wk of lactation was not different between $\mathrm{HE}$ and CON (Figure 1).

Body weight and BCS are shown in Figure 2. The HE cows gained more weight $(1.47$ vs. $0.80 \mathrm{~kg} / \mathrm{d}, P=0.03)$ during the dry period compared with the CON cows. A trend for greater BCS gain (0.37 vs. $0.14, P=0.07$ ) was observed during the dry period in HE compared with CON. No difference in calf birth weight was seen between $\mathrm{HE}$ and CON (41.0 vs. $41.2 \mathrm{~kg}$ ).

\section{Blood Parameters and Hepatic TAG and Total Lipid}

Blood parameters did not differ between the 2 groups during the transition period (Table 5). Plasma concentration of NEFA was greater $(P<0.001)$ after $(\mathrm{d} 1$ and 7) than before parturition $(\mathrm{d}-14)$ in both groups. The concentration of plasma BHBA was increased early postpartum (d 1, $P=0.002$, and d $7, P<0.001$ ) compared with before calving $(\mathrm{d}-14)$ across the groups. Plasma insulin was greater at $\mathrm{d}-14$ than at $\mathrm{d} 1(P=$ $0.03)$ and $\mathrm{d} 7(P=0.001)$ relative to parturition across treatments. Plasma glucose concentration was higher before calving than after calving $(\mathrm{d} 7, P<0.001)$ across the groups. Hepatic TAG did not differ between HE and CON cows and increased $(P<0.01)$ early postpartum (d 1 and 7 ) compared with prepartum in both groups

Table 4. Effect of prepartal dietary energy level on feed intake of dairy cows during the transition period

\begin{tabular}{|c|c|c|c|c|c|c|c|}
\hline Item & $\begin{array}{c}\text { Week } \\
\text { peripartum }\end{array}$ & \multicolumn{2}{|c|}{ Prepartal energy level ${ }^{1}$} & $\mathrm{SEM}^{2}$ & \multicolumn{3}{|c|}{$P$-value ${ }^{3}$} \\
\hline Total DMI, kg/d & $\begin{array}{r}-2 \\
-1 \\
1 \\
2\end{array}$ & $\begin{array}{l}12.7 \\
12.0 \\
16.3 \\
19.6\end{array}$ & $\begin{array}{l}14.0 \\
13.2 \\
16.0 \\
19.2\end{array}$ & 0.54 & 0.53 & $<0.001$ & 0.37 \\
\hline Forage DMI, $\mathrm{kg} / \mathrm{d}$ & $\begin{array}{r}-2 \\
-1 \\
1 \\
2\end{array}$ & $\begin{array}{r}11.0^{\mathrm{a}} \\
9.5^{\mathrm{a}} \\
11.3 \\
12.3\end{array}$ & $\begin{array}{l}12.9^{\mathrm{b}} \\
11.7^{\mathrm{b}} \\
11.3 \\
11.8\end{array}$ & 0.54 & 0.24 & 0.004 & 0.05 \\
\hline ME intake, MJ/d & $\begin{array}{r}-2 \\
-1 \\
1 \\
2\end{array}$ & $\begin{array}{l}116.9^{\mathrm{a}} \\
113.6^{\mathrm{a}} \\
185.6^{\mathrm{a}} \\
228.5^{\mathrm{a}}\end{array}$ & $\begin{array}{l}141.1^{\mathrm{b}} \\
136.5^{\mathrm{b}} \\
184.0^{\mathrm{a}} \\
225.0^{\mathrm{a}}\end{array}$ & 5.99 & 0.18 & $<0.001$ & 0.11 \\
\hline ME balance, $\mathrm{MJ} / \mathrm{d}$ & $\begin{array}{r}-2 \\
-1 \\
1 \\
2\end{array}$ & $\begin{array}{r}9.0^{\mathrm{a}} \\
5.7^{\mathrm{a}} \\
-52.4^{\mathrm{a}} \\
-54.3^{\mathrm{a}}\end{array}$ & $\begin{array}{r}31.6^{\mathrm{b}} \\
27.3^{\mathrm{b}} \\
-57.9^{\mathrm{a}} \\
-77.2^{\mathrm{a}}\end{array}$ & 6.93 & 0.66 & $<0.001$ & 0.02 \\
\hline
\end{tabular}

\footnotetext{
$\overline{\mathrm{a}, \mathrm{b}}$ Means with different superscripts indicate significant differences $(P<0.05)$ between the groups at each time point, if $P \leq 0.15$ for treatment $x$ week interaction.

${ }^{1}$ Cows fed ad libitum either grass silage (HE; MJ/d of ME, $\left.\mathrm{n}=8\right)$ or TMR (CON; $109 \mathrm{MJ} / \mathrm{d}$ of ME, $\left.\mathrm{n}=8\right)$ during the dry period.

${ }^{2}$ Largest SEM is shown.

${ }^{3}$ Trt $=$ treatment; $\mathrm{Wk}=$ week.
} 


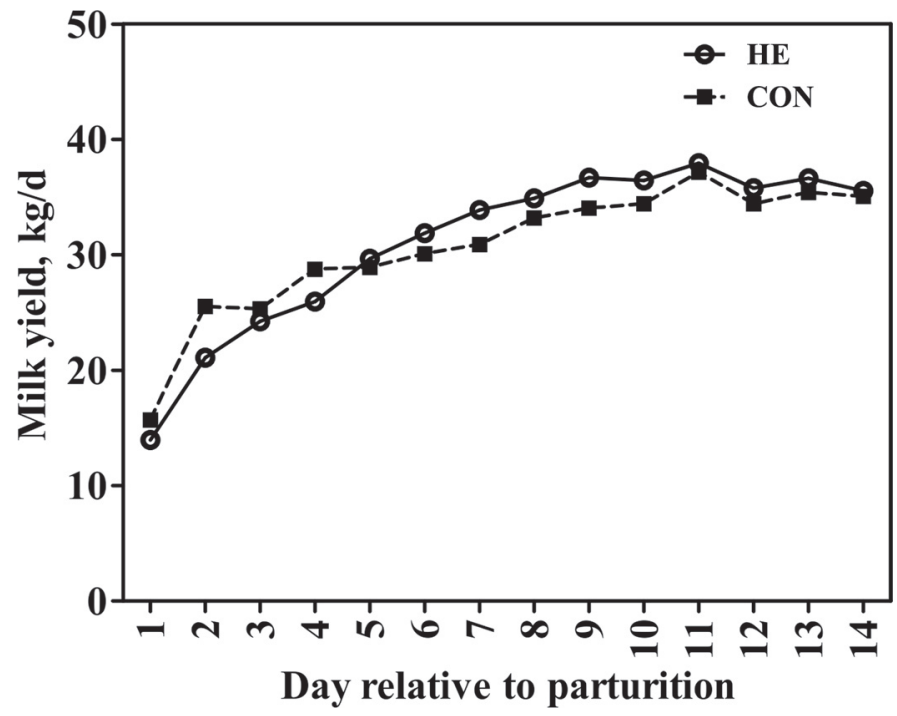

Figure 1. Daily milk yield $(\mathrm{kg} / \mathrm{d})$ during the first 2 wk of lactation in dairy cows fed ad libitum either grass silage (HE; $144 \mathrm{MJ} / \mathrm{d}$ of ME) or TMR (CON; $109 \mathrm{MJ} / \mathrm{d}$ of ME) during the dry period. Values are expressed as LSM. SEM $=0.922$; treatment effect, $P=0.70$; day, $P<$ 0.001 ; treatment $\times$ day, $P=0.96$.

(Table 5). A significant treatment $\times$ day interaction $(P=0.03)$ was observed in hepatic total lipid content, characterized by a tendancy toward a delayed increase of total lipid content in $\mathrm{HE}$ compared with $\mathrm{CON}$ at d 1 postpartum $(P=0.15)$.

\section{Hepatic Gene Expression}

The mRNA abundances of hepatic genes are presented in Table 6. A treatment $\times$ day interaction $(P=0.03)$ was observed for $P C K 1$, characterized by a tendency toward lower mRNA expression in the $\mathrm{HE}$ cows at $\mathrm{d} 1$ $(P=0.12)$ and $7(P=0.10)$ postpartum compared with the CON cows, whereas no difference was detected at $\mathrm{d}$ 14 before parturition between the groups. The prepartal dietary energy level did not alter the expression of other studied genes. The mRNA abundances of retinol binding protein $4(R B P 4 ; P=0.001)$ and $N F K B 1(P$ $=0.005)$ were downregulated, and that of PPARA ( $P$ $=0.15)$ was upregulated immediately after parturition at d 1 compared with before parturition. However, no difference in the mRNA expression of RBP 4, NFKB1, or PPARA was observed between $\mathrm{d}-14$ and 7 relative to calving across the groups. A decrease in the mRNA of PPARA was observed in $\mathrm{d} 7$ compared with $\mathrm{d} 1$ postcalving in both groups $(P=0.03)$. The mRNA abundance of PPARG was downregulated, whereas DGAT1 was upregulated postpartum (d 1 and 7) compared with prepartum $(P<0.05)$.
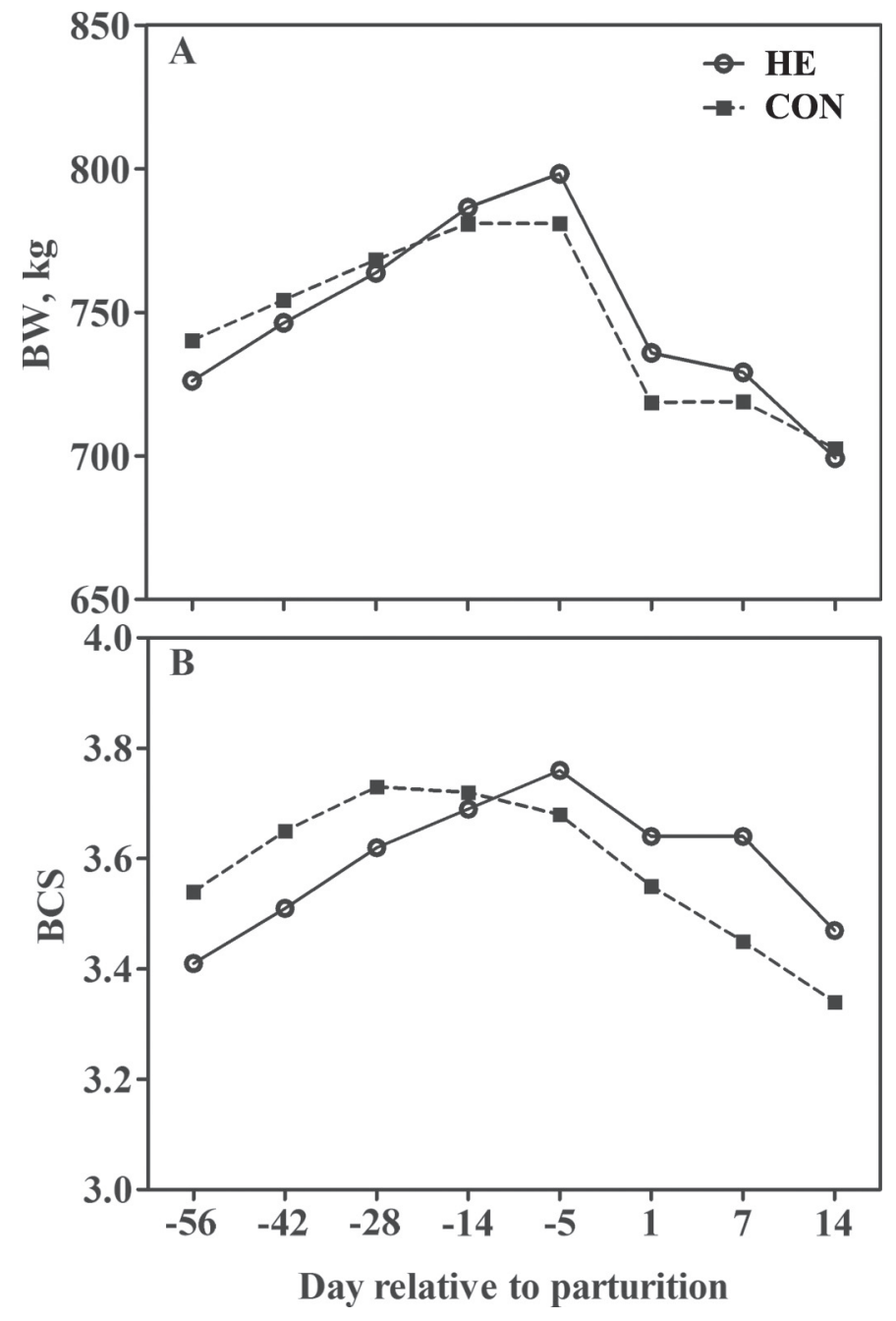

Figure 2. Body weight (A) and BCS (B) of dairy cows fed ad libitum either grass silage (HE; $144 \mathrm{MJ} / \mathrm{d}$ of ME) or TMR (CON; 109 $\mathrm{MJ} / \mathrm{d}$ of ME) during the dry period. Values are expressed as LSM. $\mathrm{SEM}$ for $\mathrm{BW}=37.97$; treatment effect, $P=0.88$; day, $P<0.001$; treatment $\times$ day, $P=0.36$. SEM for $\mathrm{BCS}=0.19$; treatment effect, $P$ $=0.95$; day, $P<0.001$; treatment $\times$ day, $P=0.36$.

\section{SAT Gene Expression}

The expression patterns of SAT candidate genes are presented in Table 7. A trend for lower $(P=0.08)$ mRNA abundance of adiponectin receptor 1 and 2 (ADIPOR1 and ADIPOR2) was noticed in the HE group compared with the CON group. However, we did not observe any treatment effect on $A D I P O Q$ gene expression during the transition period. A treatment $x$ day interaction $(P=0.04)$ was observed for $L E P$, with lower mRNA expression in HE compared with CON at d 7 postpartum $(P=0.005)$. A trend for a treatment $\times$ day interaction was found for stearoyl-CoA desaturase ( $S C D$; treatment $\times$ day, $P=0.13$ ), characterized by a tendency toward lower mRNA abundance at $\mathrm{d} 7$ post- 
SELIM ET AL.

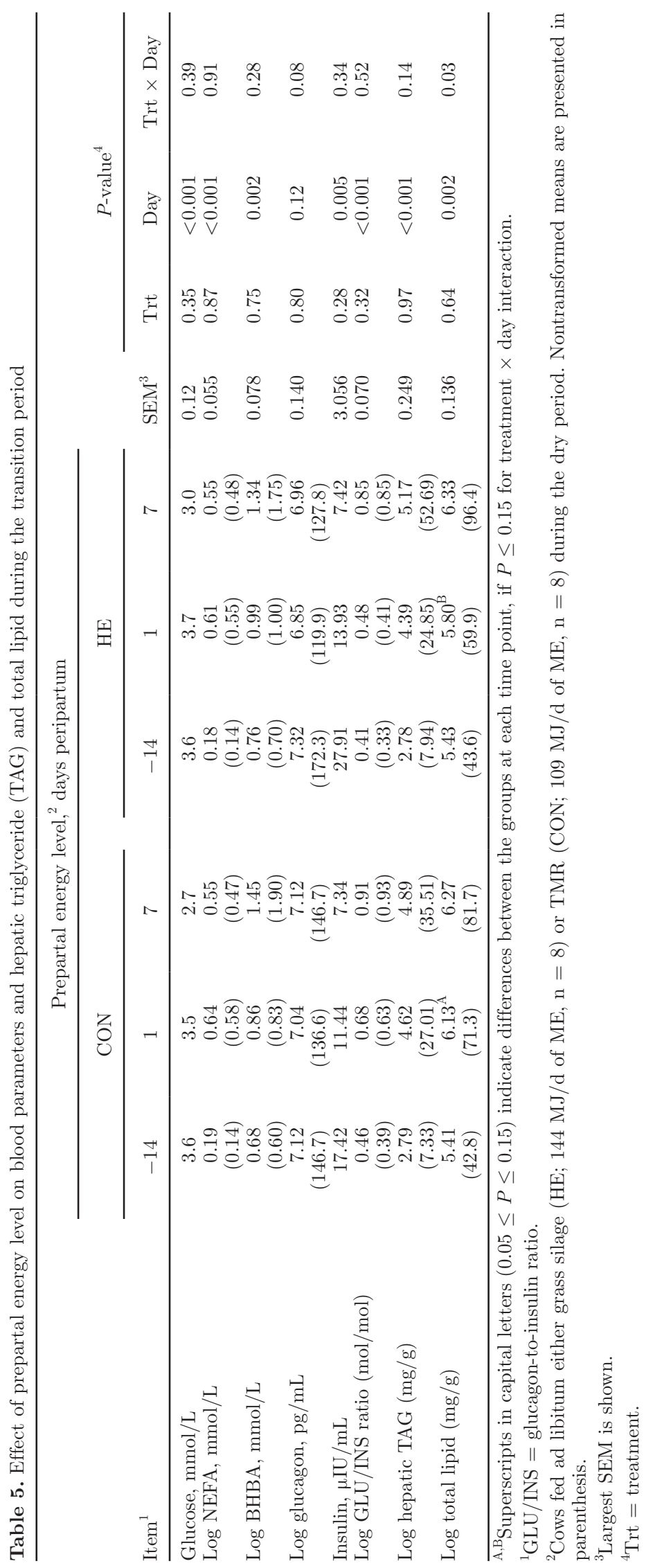


Table 6. Effect of prepartal dietary energy level on the relative mRNA abundance of hepatic genes $\left[\log _{2}(18-\Delta \mathrm{Ct})\right]$ during the transition period

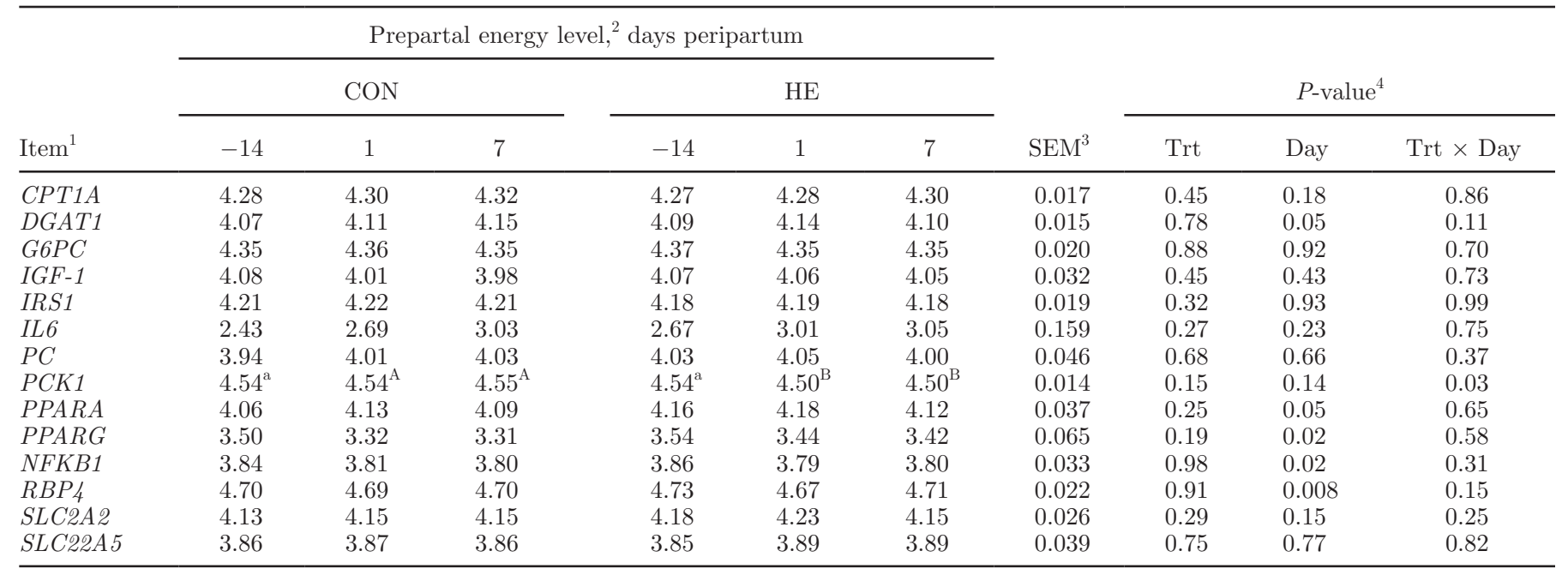

${ }_{\mathrm{a} ; \mathrm{A}, \mathrm{B}}$ Superscripts in lowercase $(P<0.05)$ and capital $(0.05 \leq P \leq 0.15)$ letters indicate differences between the groups at each time point, if $P$ $\leq 0.15$ for treatment $\times$ day interaction.

${ }^{1} C P T 1 A=$ mitochondrial carnitine palmitoyltransferase $1 \mathrm{~A} ; D G A T 1=$ diacylglycerol O-acyltransferase $1 ; G 6 P C=$ glucose-6-phosphatase catalytic subunit; $I G F-1=$ insulin-like growth factor $1 ; I R S 1=$ insulin receptor substrate 1 transcript variant $1 ; I L 6=$ interleukin $6 ; P C=$ pyruvate carboxylase; $P C K 1=$ cytosolic phosphoenolpyruvate carboxykinase $1 ; P P A R A=$ peroxisome proliferator-activated receptor $\alpha ; P P A R G=$ peroxisome proliferator-activated receptor gamma; $N F K B 1=$ nuclear factor of kappa light polypeptide gene enhancer in B-cells $1 ; R B P 4=$ retinol binding protein $4 ; S L C 2 A 2=$ solute carrier family 2 (facilitated glucose transporter), member $2 ; S L C 22 A 5=$ solute carrier family 22 (organic cation/carnitine transporter), member 5 .

${ }^{2}$ Cows fed ad libitum either grass silage (HE; $144 \mathrm{MJ} / \mathrm{d}$ of ME) or TMR (CON; $109 \mathrm{MJ} / \mathrm{d}$ of ME) during the dry period.

${ }^{3}$ Largest SEM is shown.

${ }^{4} \mathrm{Trt}=$ treatment.

partum $(P=0.08)$ in HE than in CON. A tendency for a treatment $\times$ day interaction was observed for lipoprotein lipase ( $L P L$; treatment $\times$ day, $P=0.15$ ), characterized by lower mRNA abundance at d 7 postpartum $(P=0.02)$ in $\mathrm{HE}$ compared with CON. The mRNA of mitochondrial carnitine palmitoyltransferase 1A $(C P T 1 A)$ was increased [d 1 and $7(P<0.05)]$, and that of $S C D$ decreased $[\mathrm{d} 1(P=0.004)$ and $7(P=$ 0.009)] postpartum compared with prepartum across the groups. A trend for a treatment $\times$ day interaction $(P=0.13)$ was observed for hormone sensitive lipase ( LIPE); however, no differences between $\mathrm{HE}$ and CON were noted at any time point. There were no treatmentor time-related differences in the mRNA expression of PPARG during the transition period.

\section{DISCUSSION}

Some recent studies have assessed the effects of dry period overfeeding of energy, primarily by increasing the dietary proportion of corn silage and corn grain, on the liver or SAT gene expression during the transition period (e.g., Ji et al., 2012; Graugnard et al., 2013; Khan et al., 2014). In the current study, however, the effects of ad libitum feeding of grass silage through the dry period on the expression of genes involved in major metabolic pathways in the liver and SAT were evaluated simultaneously.

Total DMI and ME intake of CON were successfully controlled during the entire dry period by the inclusion of wheat straw in TMR, as previously reported (Dann et al., 2006; Ji et al., 2012). In spite of the greater BW change in cows fed HE, a relatively small difference in BCS change was observed between the groups during the dry period. Our results suggest that cows in the HE group may have accumulated more visceral AT than cows in the CON group prepartum. A recent study by Drackley et al. (2014) reported that feeding a highenergy diet to nonlactating, nonpregnant dairy cows resulted in greater final BW and increased internal AT mass without significant increase in BCS. Further, they stated that BCS may not be sensitive enough to detect changes of visceral fat stores. The potential involvement of internal AT in metabolic disorders of periparturient dairy cows in response to prepartal energy intake is not well studied.

\section{Effect of Overfeeding on Hepatic Gene Expression}

Prepartal ad libitum feeding of grass silage downregulated hepatic PCK1 mRNA expression early postpartum compared with CON, suggesting lower gluconeo- 
Table 7. Effect of prepartal dietary energy level on the relative mRNA abundance of subcutaneous adipose tissue genes $\left[\log _{2}(18-\Delta \mathrm{Ct})\right]$ during the transition period

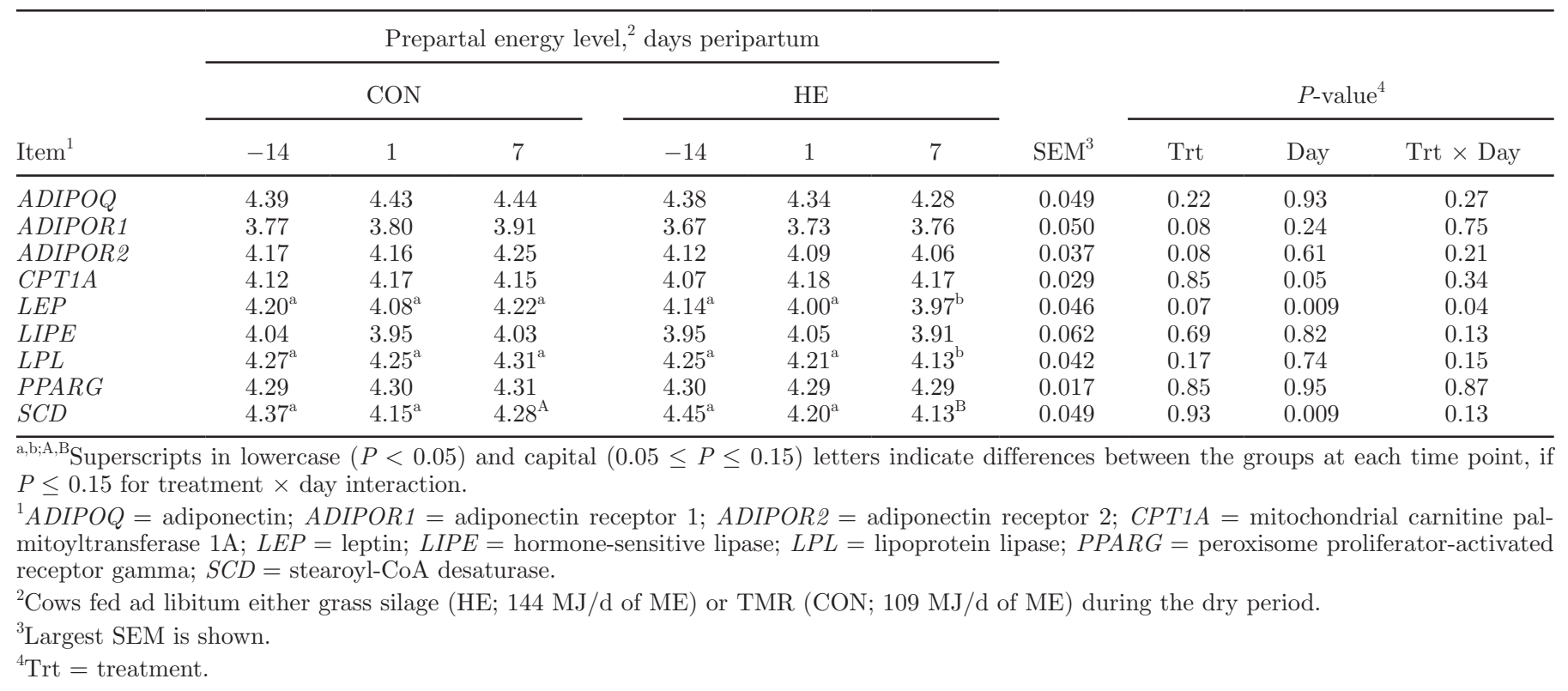

genic capacity from propionate in $\mathrm{HE}$, whereas $P C K 1$ expression was maintained at the same level in $\mathrm{CON}$ before and after calving. Earlier studies have suggested that overfeeding of energy may affect hepatic PCK1 gene expression via high blood insulin concentration (Selim et al., 2014) or enzyme activity via hepatic TAG accumulation (Murondoti et al., 2004). Increased starch content in the close-up diet in the study by Selim et al. (2014) could have increased the molar proportion of propionate in the rumen, and increased absorption of propionate may have stimulated insulin secretion. Because the plasma insulin and glucagon concentrations and hepatic TAG content were not significantly different between the groups during the transition period in the present study, and a delayed increase in hepatic TL very near parturition was observed in HE, no clear explanation exists for lower PCK1 gene expression in the HE cows.

Pyruvate carboxylase $(P C)$ is required for the entry of lactate and the major glucogenic AA, alanine, into gluconeogenesis. The lack of treatment or time-related change in the mRNA expression of $P C$ in both groups around parturition was unexpected and in contrast to the findings from other studies (Loor et al., 2006; Selim et al., 2014). In a grass silage diet, the production of propionate in the rumen is low and, thus, part of the AA in absorbed protein may be used as an important source of glucose via hepatic gluconeogenesis (Vanhatalo et al., 2003). Therefore, the absence of concentrate in the prepartal diet may have increased $P C$ expression at the time of first biopsy $(-14 \mathrm{~d})$. In addition, the smaller change of glucagon-to-insulin ratio in the current study than in the study by Selim et al. (2014) could explain the lack of time effect on $P C$. A recent study by Larsen and Kristensen (2013) has shown that increased use of endogenous glucogenic precursors, lactate and alanine, is quantitatively the most important adaptation to support the increased glucose demand after calving. The greater expression of $P C$ has been induced by feed restriction and negative energy balance (NEB) in dairy cows (Velez and Donkin, 2005; Akbar et al., 2013). Thus, it was not expected that the onset of NEB had no effect on $P C$ expression in the present study.

The absence of differences in the mRNA abundances of glucose-6-phosphatase catalytic subunit $($ G6PC) and solute carrier family 2 (facilitated glucose transporter), member 2 (SLC2A2) suggest that hepatic glucogenic status, particularly glucose release from the liver (Hammon et al., 2009; Goselink et al., 2013), did not differ between the treatment groups. However, it is noteworthy that no time effect was observed in the mRNA expression of these genes, as was also reported by Hammon et al. (2009) and Goselink et al. (2013). This may imply that major changes in hepatic glucose release in transition cows are not regulated by the expression levels of these genes or alternative systems for glucose transport exist (Fehr et al., 2005), given the rapid increase of glucose release after parturition (Larsen and Kristensen, 2013).

Prepartal ad libitum feeding of grass silage did not affect the mRNA expression of CPT1A, DGAT1, or solute carrier family 22 (organic cation/carnitine transporter), member 5 (SLC22A5; carnitine uptake) 
around parturition. Some previous studies (Loor et al., 2006; Selim et al., 2014) have reported that ad libitum feeding prepartum may decrease the expression of $C P T 1 A$, the rate-limiting enzyme for the transport of NEFA into mitochondria, and hence FA $\beta$-oxidation, and consequently increase hepatic TAG accumulation (e.g., upregulation of DGAT1; Loor et al., 2006). In contrast, Khan et al. (2014) observed that dry period overfeeding induced upregulation of $C P T 1 A$ and linked it to increased blood NEFA concentrations. In the present study, the lack of treatment effect on $C P T 1 A$ and DGAT1 mRNA was in line with the absence of differences in blood NEFA concentration and the liver TAG content between the groups. The mRNA abundance of SLC22A5 was not different between $\mathrm{HE}$ and CON, which may indicate that hepatic ability to take up carnitine from blood stream was not affected by prepartal energy level. Furthermore, the transition from late pregnancy to early lactation was not associated with changes in the mRNA abundance of SLC22A5, in contrast to Schlegel et al. (2012). Differences in time scale and dietary treatments may be the cause of differences in results between the present study and the study by Schlegel et al. (2012).

During the transition period, neither the expression of $P P A R A$ nor $P P A R G$ was affected by prepartal dietary energy level. A possible explanation for our results is that the concentrations of blood NEFA between the groups were not different. It was shown by van Dorland et al. (2009) that minor differences in blood NEFA concentration did not affect hepatic PPARG gene expression. Our results, although with different time scale, were in agreement with Khan et al. (2014), who reported that the expression of PPARA between $\mathrm{d}-14$ and 30 relative to parturition was not different between overfed and CON cows. The observed upregulation of PPARA immediately after parturition (d 1) postpartum across the groups was probably due to an increase in blood NEFA concentration immediately postcalving (Bionaz et al., 2013). The downregulation of PPARA at d 7 compared with d 1 postpartum was in line with the declining trend of blood NEFA concentration during the first lactation week, and could explain the lack of time effect in its target genes (CPT1A, SLC22A5, and PC) around calving. The downregulation of hepatic PPARG early postpartum in the current study was in agreement with Saremi et al. (2014). Although the expression of PPARG is low in ruminant liver (Bionaz et al., 2013), it has been suggested that reduced hepatic expression of PPARG might be linked to enhanced gluconeogenic capacity or reduced FA infiltration of the liver (Saremi et al. 2014).

We did not find any effect of treatment on NFKB1 expression during the transition period, which could be related to the lack of differences in plasma NEFA and liver TAG between the 2 groups. Our findings were in contrast to Loor et al. (2006), but in line with Selim et al. (2014). The downregulation of NFKB1 immediately after parturition was contrary to Graugnard et al. (2013) and Selim et al. (2014). The increases of liver TAG (Graugnard et al., 2013) and blood NEFA (Selim et al., 2014) during the transition period were greater in these studies than in the current study, which may explain the differences between the studies. The decrease in NFKB1 expression between $\mathrm{d}-14$ and 1 relative to calving may imply that no measurable DNA damage or inflammation occurred in the liver (Loor et al., 2006; Graugnard et al., 2013). We did not find any evidence on the effect of prepartal overfeeding of energy on the mRNA abundance of interleukin 6 (IL6), which may further indicate that no difference in hepatic inflammatory status exists between the groups. Interleukin 6 appears to play a key role in the impairment of normal liver function of dairy cows during inflammation and ketosis (Loor et al., 2007; Trevisi et al., 2012).

In agreement with Selim et al. (2014), we did not find an effect of dry period energy level on the mRNA expression of $R B P$; ; however, we observed downregulation of $R B P$ \& gene expression after calving, in line with Rezamand et al. (2012). Abd Eldaim et al. (2010) also reported that plasma $R B P 4$ decreased immediately after parturition and returned to prepartum levels by 2 wk postpartum. The decline in plasma RBP4 can be attributed to its flux toward the mammary gland immediately after calving, although several factors, including inflammatory reactions and protein intake, may affect RBP4 synthesis. In contrast to present results, Selim et al. (2014) reported no time-related differences in $R B P 4$ mRNA expression at $-10,1$, and $9 \mathrm{~d}$ relative to parturition. Higher protein level and longer close-up feeding with concentrate in our previous study (Selim et al., 2014) than in the present one may explain the discrepancies in the expression patterns of $R B P 4$, as Lindberg et al. (1999) observed that higher protein intake before parturition ensured a more stable plasma $R B P 4$ concentration around parturition. In addition to its role as a retinol carrier in plasma, $R B P 4$ may play a role in obesity-induced insulin resistance and regulation of hepatic glucose production, particularly by increasing PCK1 expression (Yang et al. 2005). In the present study, we did not observe any correlation between RBP 4 and PCK1 mRNA expression, in contrast to Selim et al. (2014).

We did not observe any treatment- or time-related effects on the mRNA abundance of insulin-like growth factor $1(I G F-1)$ or insulin receptor substrate 1 transcript variant 1 (IRS1) during the periparturient period. Khan et al. (2014) reported that overfeeding 
during the dry period ( $150 \%$ of energy requirement for pregnant dairy cows) resulted in greater expression of $I G F-1$ prepartum (d -14), but no differences were noted during the first month of lactation. In their study, overfed cows had more than 5-fold greater blood insulin concentration at d 14 prepartum than control cows, which could be attributed to increased starch intake prepartum. The lack of time effect on $I G F-1$ mRNA in our study was unexpected, and contrary to the results from previous studies (Gross et al., 2011; Graugnard et al., 2013; Khan et al., 2014). Fenwick et al. (2008) reported that lactating cows kept under severe NEB had lower expression of hepatic $I G F-I$ than mild NEB cows. In our study, average NEB was $-55 \mathrm{MJ}$ of $\mathrm{ME} / \mathrm{d}$ at lactation wk 1. It is possible that differences in changes of energy balance and the degree of NEB during very early lactation explain the differences in $I G F-1$ expression between studies.

\section{Effect of Overfeeding on SAT Gene Expression}

Gene Expression of Adipokines. In the present study, the mRNA expression of $A D I P O Q$ was unaffected by treatment during the transition period, in agreement with Selim et al. (2014). However, these findings were contrary to Ji et al. (2012), who observed considerable upregulation of $A D I P O Q$ until d 7 postpartum in overfed cows. Several factors may have attributed to the differences in gene expression results between $\mathrm{Ji}$ et al. (2012) and our studies, such as breed, composition of diet, level and duration of overfeeding, and degree of fatness. In the current study, lower expression of $A D I$ $P O Q$ receptors in $\mathrm{HE}$ compared with CON cows may have reduced $A D I P O Q$ sensitivity; thus, reduced insulin sensitivity in SAT of HE may be expected (Lemor et al., 2009). The lack of changes in the expression of $A D I P O Q$ and its receptors from pregnancy to early lactation was consistent with previous studies (Giesy et al., 2012; Selim et al., 2014). Conversely, Ji et al. (2012), Khan et al. (2013), and Saremi et al. (2014) reported that the expression of $A D I P O Q$ gradually decreased during the peripartal period. However, Giesy et al. (2012) reported that plasma $A D I P O Q$ concentrations may decrease during early lactation independently of $A D I P O Q$ expression in SAT, and indicated that the formation of circulating $A D I P O Q$ complexes may be a major determinant of the plasma concentrations of this adipokine.

The decline of LEP during the transition period concurred with previous studies showing a decrease of plasma LEP concentration (Block et al., 2001; Kokkonen et al., 2005) or LEP expression (Saremi et al., 2014; Selim et al., 2014). The downregulation of LEP postpartum in both groups and particularly in the $\mathrm{HE}$ group may support the concomitant retrieval of DMI and energy balance (Roche et al., 2013). In contrast, Ji et al. (2014) reported an increase in the expression of LEP mRNA in overfed nonpregnant, nonlactating dairy cows, which may suggest the increased negative feedback from AT to decrease feed intake. Selim et al. (2014) observed that the expression of LEP was not affected by prepartal dietary energy. Differences in physiological state (Ji et al., 2014) and dietary treatments (Selim et al., 2014) complicate the comparison between the studies.

Lipogenesis and Lipolysis-Related Genes. We observed downregulation in the mRNA of $L P L$ and $S C D$ in HE cows early postpartum compared with CON cows, suggesting a more profound inhibition of lipogenesis in $\mathrm{HE}$ early postcalving. Our results were consistent with Ji et al. (2012) and Selim et al. (2014), who reported downregulation of lipogenic genes early postpartum in the overfed cows. Ji et al. (2012) suggested that this may be attributed to the exacerbated insulin resistance early postpartum. We did not observe any dietary effect on the expression of PPARG over time, which was in contrast to Ji et al. (2012), but consistent with Selim et al. (2014). A clear explanation for the downregulation of PPARG target genes without a clear change in that nuclear receptor in response to prepartal energy or lactation is not readily apparent. However, changes in PPAR target genes do not necessarily involve a noticeable change in its mRNA, and these target genes can serve as a proxy for the function of PPAR in tissues (Khan et al., 2014), as also observed for PPARA in the liver of dairy cows (van Dorland et al., 2009; Graugnard et al., 2013).

In the present study, dietary treatment and time did not affect the mRNA expression of LIPE, which was consistent with the results of Selim et al. (2014). Sumner and McNamara (2007) reported upregulation of LIPE after parturition (at d 30, 90, and 270) in comparison to the time before parturition $(-30 \mathrm{~d})$. In contrast, a recent study by Khan et al. (2013) observed downregulation of LIPE and patatin-like phospholipase domain containing 2 after parturition compared with before parturition. Basal lipolytic activity is controlled by adipose triglyceride lipase, whereas hormone-sensitive lipase is mainly responsible for stimulating lipolysis (Sumner and McNamara, 2007). Our results give support to the previous studies suggesting that posttranslational regulation has a key role in the control of lipolytic activity through stimulation of $\beta$-2-adrenergic receptor by norepinephrine and the downstream phosphorylation cascade (Loor, 2010; Khan et al. 2013).

$\boldsymbol{F A} \boldsymbol{\beta}$-Oxidation. The observed upregulation of CPT1A in SAT after parturition across the groups [2.7fold calculated by the method described by Livak and 
Schmittgen (2001)] suggests enhanced FA $\beta$-oxidation early postpartum as a result of NEB, as CPT1A is the principal regulator of translocation of long-chain FA from the cytoplasm into the mitochondria. Although, the exact role of FA $\beta$-oxidation in SAT of periparturient dairy cows is not clear, the increased CPT1A expression may be a response to AT replenishment as lactation progresses (Gao et al., 2011; Elis et al., 2013).

\section{CONCLUSIONS}

Downregulation of $A D I P O Q$ receptors, $L E P, L P L$, and $S C D$, in the overfed cows during the early postpartal period indicates that prepartal overfeeding of grass silage may have decreased lipogenesis and exacerbated insulin resistance in SAT after parturition compared with CON. Downregulation of the key gene linked to gluconeogenesis (PCK1) in the HE group early postcalving suggests that ad libitum feeding of grass silage may have attenuated the increase of hepatic gluconeogenic capacity from propionate compared with a controlled energy diet. However, no differences were noted in the expression of genes related to hepatic glucose release (G6PC and SLC2A2) between $\mathrm{HE}$ and $\mathrm{CON}$ during the transition period. Results of this study indicate that prepartal overfeeding of grass silage had fewer effects on the transcriptional adaptations of key genes involved in major metabolic pathways in the liver and SAT than previous studies that have used maize-based diets during the dry period, even when using the same levels of dietary comparison (150 vs. $100 \%$ of energy requirement of pregnant dairy cows).

\section{ACKNOWLEDGMENTS}

This study was funded by the Ministry of Agriculture and Forestry (Helsinki, Finland). S. Selim was financially supported by Raisio plc Research Foundation (Raisio, Finland). The authors thank Siru Salin (Department of Agricultural Sciences, University of Helsinki) for coordinating the trial, and gratefully appreciate the assistance of Juha Suomi and his staff at the research farm of the University of Helsinki for the care of experimental animals, and that of the laboratory staff of the Department of Agricultural Sciences, University of Helsinki. The help of Petri Auvinen and Eeva-Marja Turkki (Institute of Biotechnology, DNA Sequencing and Genomics Laboratory, Helsinki, Finland) is greatly appreciated.

\section{REFERENCES}

Abd Eldaim, M. A., A. Kamikawa, M. M. Soliman, M. M. Ahmed, Y. Okamatsu-Ogura, A. Terao, T. Miyamoto, and K. Kimura. 2010.
Retinol binding protein 4 in dairy cows: Its presence in colostrums and alteration in plasma during fasting, inflammation, and the peripartum period. J. Dairy Res. 77:27-32.

Akbar, H., M. Bionaz, D. B. Carlson, S. L. Rodriguez-Zas, R. E. Everts, H. A. Lewin, J. K. Drackley, and J. J. Loor. 2013. Feed restriction, but not L-carnitine infusion, alters the liver transcriptome by inhibiting sterol synthesis and mitochondrial oxidative phosphorylation and increasing gluconeogenesis in mid-lactation dairy cows. J. Dairy Sci. 96:2201-2213.

Andersen, C. L., J. L. Jensen, and T. F. Ørntoft. 2004. Normalization of real-time quantitative reverse transcription-PCR data: A model-based variance estimation approach to identify genes suited for normalization, applied to bladder and colon cancer data sets. Cancer Res. 64:5245-5250.

Antuna-Puente, B., B. Feve, S. Fellahi, and J. P. Bastard. 2008. Adipokines: The missing link between insulin resistance and obesity. Diabetes Metab. 34:2-11.

Bell, A. W. 1995. Regulation of organic nutrient metabolism during transition from late pregnancy to early lactation. J. Anim. Sci. 73:2804-2819.

Bionaz, M., S. Chen, M. J. Khan, and J. J. Loor. 2013. Functional role of PPARs in ruminants: Potential targets for fine-tuning metabolism during growth and lactation. PPAR Res. 2013:684159.

Bionaz, M., and J. J. Loor. 2008. Gene networks driving bovine milk fat synthesis during the lactation cycle. BMC Genomics 9:366.

Block, S. S., W. R. Butler, R. A. Ehrhardt, A. W. Bell, M. E. Van Amburgh, and Y. R. Boisclair. 2001. Decreased concentration of plasma leptin in periparturient dairy cows is caused by negative energy balance. J. Endocrinol. 171:339-348.

Bonnet, M., L. Bernard, S. Bes, and C. Leroux. 2013. Selection of reference genes for quantitative real-time PCR normalisation in adipose tissue, muscle, liver and mammary gland for ruminants. Animal 7:1344-1353.

Dann, H. M., N. B. Litherland, J. P. Underwood, M. Bionaz, A. D'Angelo, J. W. McFadden, and J. K. Drackley. 2006. Diets during far-off and close-up dry periods affect periparturient metabolism and lactation in multiparous cows. J. Dairy Sci. 89:3563-3577.

Drackley, J. K., R. L. Wallace, D. Graugnard, J. Vasquez, B. F. Richards, and J. J. Loor. 2014. Visceral adipose tissue mass in nonlactating dairy cows fed diets differing in energy density. J. Dairy Sci. 97:3420-3430.

Edmonson, A. J., I. J. Lean, L. D. Weaver, T. Farver, and G. Webster. 1989. A body condition chart of Holstein dairy cows. J. Dairy Sci. $72: 68-78$

Elis, S., S. Coyral-Castel, S. Freret, J. Cognié, A. Desmarchais, A. Fatet, C. Rame, E. Briant, V. Maillard, and J. Dupont. 2013. Expression of adipokine and lipid metabolism genes in adipose tissue of dairy cows differing in a female fertility quantitative trait locus. J. Dairy Sci. 96:7591-7602.

Fehr, M., H. Takanaga, D. W. Ehrhardt, and W. B. Frommer. 2005. Evidence for high-capacity bidirectional glucose transport across the endoplasmic reticulum membrane by genetically encoded fluorescence resonance energy transfer nanosensors. Mol. Cell. Biol. 25:11102-11112.

Fenwick, M. A., R. Fitzpatrick, D. A. Kenny, M. G. Diskin, J. Patton, J. J. Murphy, and D. Claire Wathes. 2008. Interrelationships between negative energy balance (NEB) and IGF regulation in liver of lactating dairy cows. Domest. Anim. Endocrinol. 34:31-44.

Gao, X., K. Li, X. Hui, X. Kong, G. Sweeney, Y. Wang, A. Xu, M. Teng, P. Liu, and D. Wu. 2011. Carnitine palmitoyltransferase 1A prevents fatty acid-induced adipocyte dysfunction through suppression of c-Jun N-terminal kinase. Biochem. J. 435:723-732.

Giesy, S. L., B. Yoon, W. B. Currie, J. W. Kim, and Y. R. Boisclair. 2012. Adiponectin deficit during the precarious glucose economy of early lactation in dairy cows. Endocrinology 153:5834-5844.

Goselink, R. M., J. van Baal, H. C. Widjaja, R. A. Dekker, R. L. Zom, M. J. de Veth, and A. M. van Vuuren. 2013. Effect of rumenprotected choline supplementation on liver and adipose gene expression during the transition period in dairy cattle. J. Dairy Sci. 96:1102-1116. 
Graugnard, D. E., K. M. Moyes, E. Trevisi, M. J. Khan, D. Keisler, J. K. Drackley, G. Bertoni, and J. J. Loor. 2013. Liver lipid content and inflammometabolic indices in peripartal dairy cows are altered in response to prepartal energy intake and postpartal intramammary inflammatory challenge. J. Dairy Sci. 96:918-935.

Gross, J., H. A. van Dorland, F. J. Schwarz, and R. M. Bruckmaier. 2011. Endocrine changes and liver mRNA abundance of somatotropic axis and insulin system constituents during negative energy balance at different stages of lactation in dairy cows. J. Dairy Sci. 94:3484-3494

Grummer, R. R., D. G. Mashek, and A. Hayirli. 2004. Dry matter intake and energy balance in the transition period. Vet. Clin. North Am. Food Anim. Pract. 20:447-470.

Hammon, H. M., G. Stürmer, F. Schneider, A. Tuchscherer, H. Blum, T. Engelhard, A. Genzel, R. Staufenbiel, and W. Kanitz. 2009. Performance and metabolic and endocrine changes with emphasis on glucose metabolism in high-yielding dairy cows with high and low fat content in liver after calving. J. Dairy Sci. 92:1554-1566.

Ji, P., J. K. Drackley, M. J. Khan, and J. J. Loor. 2014. Overfeeding energy upregulates peroxisome proliferator-activated receptor $(\mathrm{PPAR}) \gamma$-controlled adipogenic and lipolytic gene networks but does not affect proinflammatory markers in visceral and subcutaneous adipose depots of Holstein cows. J. Dairy Sci. 97:3431-3440.

Ji, P., J. S. Osorio, J. K. Drackley, and J. J. Loor. 2012. Overfeeding a moderate energy diet prepartum does not impair bovine subcutaneous adipose tissue insulin signal transduction and induces marked changes in peripartal gene network expression. J. Dairy Sci. 95:4333-4351

Kadegowda, A. K., M. Bionaz, B. Thering, L. S. Piperova, R. A Erdman, and J. J. Loor. 2009. Identification of internal control genes for quantitative polymerase chain reaction in mammary tissue of lactating cows receiving lipid supplements. J. Dairy Sci. 92:2007-2019.

Khan, M. J., A. Hosseini, S. Burrell, S. M. Rocco, J. P. McNamara, and J. J. Loor. 2013. Change in subcutaneous adipose tissue metabolism and gene network expression during the transition period in dairy cows, including differences due to sire genetic merit. J. Dairy Sci. 96:2171-2182.

Khan, M. J., C. B. Jacometo, D. E. Graugnard, M. N. Corrêa, E. Schmitt, F. Cardoso, and J. J. Loor. 2014. Overfeeding dairy cattle during late-pregnancy alters hepatic PPARA-regulated pathways including hepatokines: Impact on metabolism and peripheral insulin sensitivity. Gene Regul. Syst. Bio. 8:97-111.

Kokkonen, T., J. Taponen, T. Anttila, L. Syrjala-Qvist, C. Delavaud, Y. Chilliard, M. Tuori, and A. T. Tesfa. 2005. Effect of body fatness and glucogenic supplement on lipid and protein mobilization and plasma leptin in dairy cows. J. Dairy Sci. 88:1127-1141.

Larsen, M., and N. B. Kristensen. 2013. Precursors for liver gluconeogenesis in periparturient dairy cows. Animal 7:1640-1650.

Lemor, A., A. Hosseini, H. Sauerwein, and M. Mielenz. 2009. Transition period-related changes in the abundance of the mRNAs of adiponectin and its receptors, of visfatin, and of fatty acid binding receptors in adipose tissue of high-yielding dairy cows. Domest. Anim. Endocrinol. 37:37-44.

Lindberg, L. A., H. Sinkkonen, A. R. Pösö, A. T. Tesfa, and J. Schröder. 1999. Production of monoclonal antibodies and enzyme immunoassay to bovine retinol-binding protein and determination of retinol-binding protein serum levels and retinol concentrations in serum and liver in dairy cows before and after parturition. Res. Vet. Sci. 66:259-263.

Livak, K. J., and T. D. Schmittgen. 2001. Analysis of relative gene expression data using real-time quantitative PCR and the 2(-Delta Delta C(T)). Methods 25:402-408.

Loor, J. J. 2010. Genomics of metabolic adaptations in the peripartal cow. Animal 4:1110-1139.

Loor, J. J., H. M. Dann, N. A. Guretzky, R. E. Everts, R. Oliveira, C. A. Green, N. B. Litherland, S. L. Rodriguez-Zas, H. A. Lewin, and J. K. Drackley. 2006. Plane of nutrition prepartum alters hepatic gene expression and function in dairy cows as assessed by longitudinal transcript and metabolic profiling. Physiol. Genomics $27: 29-41$
Loor, J. J., R. E. Everts, M. Bionaz, H. M. Dawn, D. E. Morin, R. Oliveira, S. L. Rodriguez-Zas, J. K. Drackley, and H. A. Lewin. 2007. Nutrition-induced ketosis alters metabolic and signaling gene networks in liver of periparturient dairy cows. Physiol. Genomics 32:105-116.

LUKE. 2015. Feed tables and nutrient requirements. Natural Resources Institute Finland. Accessed Jan. 5, 2015. http://www.mtt.fi/ feedtables.

Murondoti, A., R. Jorritsma, A. C. Beynen, T. Wensing, and M. J. H. Geelen. 2004. Activities of the enzymes of hepatic gluconeogenesis in periparturient dairy cows with induced fatty liver. J. Dairy Res. 71:129-134.

Rezamand, P., J. S. Watts, K. M. Hunt, B. J. Bradford, L. K. Mamedova, and S. D. Morey. 2012. Bovine hepatic and adipose retinolbinding protein gene expression and relationship with tumor necrosis factor- $\alpha$. J. Dairy Sci. 95:7097-7104.

Roche, J. R., A. W. Bell, T. R. Overton, and J. J. Loor. 2013. Nutritional management of the transition cow in the 21st century-A paradigm shift in thinking. Anim. Prod. Sci. 53:1000-1023.

Rozen, S., and H. Skaletzky. 2000. Primer3 on the WWW for general users and for biologist programmers. Pages 365-386 in Bioinformatics Methods and Protocols: Methods in Molecular Biology. S. Krawetz and S. Misener, ed. Humana Press, Totowa, NJ.

Ruijter, J. M., C. Ramakers, W. M. H. Hoogaars, Y. Karlen, O. Bakker, M. J. B. van den Hoff, and A. F. M. Moorman. 2009. Amplification efficiency: Linking baseline and bias in the analysis of quantitative PCR data. Nucleic Acids Res. 37:e45.

Salin, S., J. Taponen, K. Elo, I. Simpura, A. Vanhatalo, R. Boston, and T. Kokkonen. 2012. Effects of abomasal infusion of tallow or camelina oil on responses to glucose and insulin in dairy cows during late pregnancy. J. Dairy Sci. 95:3812-3825.

Saremi, B., S. Winand, P. Friedrichs, A. Kinoshita, J. Rehage, S. Dänicke, S. Häussler, G. Breves, M. Mielenz, and H. Sauerwein. 2014 Longitudinal profiling of the tissue-specific expression of genes related with insulin sensitivity in dairy cows during lactation focusing on different fat depots. PLoS ONE 9:e86211.

Schlegel, G., J. Keller, F. Hirche, S. Geißler, F. J. Schwarz, R. Ringseis, G. I. Stangl, and K. Eder. 2012. Expression of genes involved in hepatic carnitine synthesis and uptake in dairy cows in the transition period and at different stages of lactation. BMC Vet. Res. 8:28.

Selim, S., S. Salin, J. Taponen, A. Vanhatalo, T. Kokkonen, and K. T. Elo. 2014. Prepartal dietary energy alters transcriptional adaptations of the liver and subcutaneous adipose tissue of dairy cows during the transition period. Physiol. Genomics 46:328-337.

Starke, A., A. Haudum, R. Busche, M. Beyerbach, S. Dänicke, and J. Rehage. 2010. Technical note: Analysis of total lipid and triacylglycerol content in small liver biopsy samples in cattle. J. Anim. Sci. 88:2741-2750.

Sumner, J. M., and J. P. McNamara. 2007. Expression of lipolytic genes in the adipose tissue of pregnant and lactating Holstein dairy cattle. J. Dairy Sci. 90:5237-5246.

Trevisi, E., M. Amadori, S. Cogrossi, E. Razzuoli, and G. Bertoni. 2012. Metabolic stress and inflammatory response in high-yielding, periparturient dairy cows. Res. Vet. Sci. 93:695-704.

van Dorland, H. A., S. Richter, I. Morel, M. G. Doherr, N. Castro, and R. M. Bruckmaier. 2009. Variation in hepatic regulation of metabolism during the dry period and in early lactation in dairy cows. J. Dairy Sci. 92:1924-1940.

Vanhatalo, A., P. Huhtanen, and T. Varvikko. 2003. Effect of various glucogenic sources on production and metabolic responses of dairy cows fed grass silage based diets. J. Dairy Sci. 86:3249-3259.

Velez, J. C., and S. S. Donkin. 2005. Feed restriction induces pyruvate carboxylase but not phosphoenolpyruvate carboxykinase in dairy cows. J. Dairy Sci. 88:2938-2948.

Yang, Q., T. E. Graham, N. Mody, F. Preitner, O. D. Peroni, J. M. Zabolotny, K. Kotani, L. Quadro, and B. B. Kahn. 2005. Serum retinol binding protein 4 contributes to insulin resistance in obesity and type 2 diabetes. Nature 436:356-362. 